\title{
The clinical and therapeutic uses of MDM2 and PSMA and their potential interaction in aggressive cancers
}

\begin{abstract}
Prostate-specific membrane antigen (PSMA) overexpression is observed in the neovasculature of solid tumors, but not in the vasculature of normal tissues. Increased PSMA expression is positively associated with tumor stage and grade, although its function in cancer remains unclear. Mouse double minute 2 (MDM2) is a negative regulator of the p53 tumor suppressor and is reported to regulate VEGF expression and angiogenesis. Both proteins have been considered as biomarkers and therapeutic targets for advanced solid tumors. Our work and a recent microarray-based gene profiling study suggest there could be signaling interplay between MDM2 and PSMA. We herein review the mechanisms underlining the outgrowth of tumors associated with PSMA and MDM2, their potential interaction and how this may be applied to anticancer therapeutics.
\end{abstract}

Keywords: interplay $\bullet$ MDM2 $\bullet$ PSMA $\bullet$ therapy $\bullet$ tumor

\section{Tumorigenesis \& clinical relevance of MDM2}

The transformation potential of Mouse double minute 2 (MDM2) was discovered when it was revealed that MDM2 can bind to the $\mathrm{p} 53$ tumor suppressor and thus inhibit its transactivation. Since then, in vivo experiments have provided compelling evidence toward the importance of the MDM2/p53 interaction [1].

The $\mathrm{p} 53$ protein transcriptionally activates many genes, including the $m d m 2$ gene [2] Therefore, $\mathrm{p} 53$ is regulated at protein level by MDM2, but once active, p 53 triggers the transcription of the $m d m 2$ gene, locking the proteins into a tight negative feedback loop, vital for cell survival [3].

Apart from its involvement in p53-dependent activities, MDM2 also plays a role in p53-independent cellular functions which contribute to tumorigenesis [4]. It is now known that MDM2 binds and regulates many proteins independent of $\mathrm{p} 53$, including proteins involved in DNA repair, DNA replication, cell-cycle control and apoptosis. These pathways work in chorus to preserve the integrity of genetic information and it has been suggested that MDM2 may act as a central node in the regulation of genome stability and, hence, transformation [5].

MDM2 is overexpressed due to amplification in around $10 \%$ of all human cancers, and overexpression via other mechanisms also occurs in many human malignancies [6]. This means that development of a therapy involving the inhibition of MDM2 could be used to treat many different patients with various cancer types. Therefore, MDM2 is a major target for drug companies in the development of therapies for cancer patients.

\section{MDM2 as a therapeutic target}

The main focus of most therapeutics targeted at MDM2 is to decrease the level of MDM2 protein in cells and therefore allow the reactivation of $\mathrm{p} 53$. There are several approaches undertaken to accomplish this: reducing MDM2 levels in cancer cells, inhibiting the E3 ubiquitin ligase complex of MDM2 or the disrupting the interaction between $\mathrm{p} 53$ and MDM2 [7].

A basic strategy to decreasing MDM2 protein expression is to specifically target
Robyn Bradbury ${ }^{1}$, Wen G Jiang $^{1}$ \& Yu-Xin Cui*,1 ${ }^{1}$ Cardiff China Medical Research Collaborative, School of Medicine, Cardiff University, UK *Author for correspondence: Tel.: +44 2920687070 cuiy7@cardiff.ac.uk 
the gene using small interfering RNA (siRNA), short hairpin RNA (shRNA) or miRNA approaches [8]. The downregulation of MDM2 using antisense oligonucleotides has led to the stabilization and activation of the p53 pathway in cancer cells growing in culture and in tumor xenograft mice. Interestingly, mutant p 53 cells have responded equally as well as those harboring wildtype $\mathrm{p} 53$. This result supports the notion that MDM2 has other p53-independent activities involved in its contribution to tumor growth and progression [9].

Another way to reactivate p 53 activity is to inhibit the ubiquitin ligase activity of MDM2 [10]. Recently, small-molecule inhibitors have been discovered which specifically target the E3 ligase activity of MDM2. Numerous compounds from this group of inhibitors have been shown to inhibit in vitro p53 ubiquitination [11]. Studies using cancer cells reported that these molecules activate p53 signaling and thus induced apoptosis. However, these compounds have shown low potency and selectivity, with more optimization being vital before assessment of the therapy's potential [11,12].

Small molecule inhibitors of the MDM2-p53 interaction have been identified, with the logic that disruption of binding will lead to a degradation of $\mathrm{p} 53$. In the past decade, much effort has been invested in this approach, with a recent yield of the first potent and selective pharmacological activators of wild-type $\mathrm{p} 53$. A few of these small molecules do represent viable leads for the development of therapeutic agents. The first of these MDM2 antagonists, the nutlins, were identified from a class of compounds named cis-imidazoles [13,14]. The nutlins displace $\mathrm{p} 53$ from MDM2 in vitro and crystal structures have shown that they bind to the p53 pocket of MDM2 in a way which remarkably mimics the molecular interactions between the two proteins. Proliferating cancer cells have been shown to be effectively blocked in the G1 and G2 phases and undergo apoptosis following treatment with these inhibitors [13]. The nutlins were the first molecules to prove that activation of wild-type $\mathrm{p} 53$ using pharmacological inhibitors of the MDM2-p53 interaction was a feasible therapeutic concept. As predicted by the molecular mechanism, it seems that only cells with wild-type $\mathrm{p} 53$ are sensitive to these compounds, so p53 status of tumors would need to be determined before any therapeutic approach is undertaken. In vitro and in vivo studies conducted using the nutlins have verified their antitumor effect [15].

Recently, there has been an influx of small molecule MDM2 inhibitors undergoing clinical trials, with seven currently in Phase I, all of which target the interaction between MDM2 and p53 [16]. The first of these, AM 232 was discovered through studies into AM 8553, a compound produced using de novo design strategy based on the structure of MDM2. AM 232 targets a shallow cleft on the surface of MDM2; has been found to be potent and selective; and has shown notable antitumoral activity in vivo [17,18]. Roche currently have two compounds in trials, R05045337 (RG7112) and R05503781 (RG7388), with R05045337 being based on the original Nutlin family of inhibitors [19]. R05503781 is the second generation of R05045337, with superior potency and selectivity [20]. Novartis have developed a drug named CGM097 which has been optimized and moved to clinical trials, with analogs currently being developed and their efficacy assessed in vivo [21]. A fifth inhibitor, named DS-3032b was developed by Daiichi Sankyo following a miniaturized thermal denaturation assay used to screen chemical libraries, leading to a unique series of benzodiazepinedione antagonists of the MDM2-p53 interaction being discovered [22]. SAR4058383 was developed by the University of Michigan and Sanofi, with promising early studies showing that a single optimized oral dose of the compounds leading to complete tumor regression in the SJSA-1 cell line model [23]. Finally, MK-8242 was developed by Merck Sharp \& Dohme Corp and a clinical trial of patients with solid tumors was recently completed [16].

It is well known that, following DNA damage, p53 is activated and this leads to arrest of the cell cycle and apoptosis in sensitive tissues [24]. Therefore, a main concern of using therapeutics to activate p53 is the effect of this act in normal tissues. Mice with MDM2 reduced to around $30 \%$ of its normal level show increased $\mathrm{p} 53$ in all tissues tested. Apart from slight disturbances in hematopoiesis and an increase in apoptosis in the small intestine, these mice developed normally $[12,25]$. Further, nude mice can tolerate nutlin-3 for 3 weeks at doses that cause inhibition and regression of tumors [15]. It seems that these studies suggest that perhaps activation of $\mathrm{p} 53$ through MDM2 inhibition may be a promising therapeutic option and can be well tolerated in vivo [12].

Although use of these inhibitors can be extremely useful for cancer therapeutic development, their effectiveness depends on multiple factors. First, as already mentioned, the therapeutic effect of p53 activation could be abolished through the potential cell cycle arrest or cell death caused by p 53 activation. Second, MDM2 is not the only regulator of p53 in cells, so other interactors may hinder the cellular response to MDM2 antagonists. For example, MDMX, another p53-binding protein, cannot be displaced by nutlin-3, so the effectiveness of nutlins can be compromised in tumor cells which overexpress MDMX [12].

Therefore, although MDM2 represents a useful and potent target for inhibitors in the impedance of can- 
cer progression, an ideal therapeutic has not yet been identified. However, with our new understanding of the functions of p53-dependent and -independent MDM2 and accelerating speed of drug development, it is possible that an MDM2-targeted therapy could be effectively applied to halt tumor outgrowth in patients (clinical trials of MDM2-targeted therapeutics summarized in Table 1 [26]).

\section{Clinical relevance of PSMA}

Prostate-specific membrane antigen (PSMA) has only a few sites of expression in normal tissues: the prostate epithelium, the kidney proximal tubules, the nervous system glial cells and the small bowel jejunal brush border $[27,28]$. At the jejunal brush border the protein is better known as FOLH1 and here it converts dietary folate (pteroylpolyglutamate) to monoglutamated folate $[29,30]$. In the nervous system, however, PSMA carries out its $\mathrm{N}$-acetylated alpha-linked acidic dipeptidase (NAALADase) function and hydrolyses $\mathrm{N}$-acetylaspartylglutamic acid (NAAG), the most abundant peptide neurotransmitter in the mammalian nervous system $[30,31]$. The presence of PSMA in the prostate and proximal tubules of the kidneys is not yet understood but it has been suggested that this could be due to the reuptake of folate in the kidneys and the release of monoglutamated folates into the seminal fluid [30].

The cell surface expression of PSMA has been shown to increase directly in cancers of higher grade, metastases, prostate cancer which is castration-resistant and cancers giving an adverse clinical outcome [32,33]. Furthermore, PSMA expression was observed to decrease in the prostate cancer cell line, LNCap, when incubated with androgen dihydrotestosterone and, conversely, cells grown in androgen-stripped media displayed increased PSMA expression [34]. It is clear that increased expression and enzymatic activity of PSMA in aggressive tumors are telling of a selective advantage bestowed by PSMA upon tumor cells and this contributes to prostate carcinogenesis [35].

PSMA has also been reported to be expressed in the neovasculature of a considerable majority of malignant solid tumors (bladder, breast, kidney pancreas, lung and melanoma), but not in the corresponding normal vasculature [36].

PSMA has been identified as an excellent target for imaging and therapy of cancer for several reasons. The specificity of its expression is a key factor, with only a limited number of normal tissue types expressing the protein, along with PSMA's large extracellular region allowing therapeutics to be exclusively targeted to the

Table 1. Clinical trials targeting mouse double minute 2 for cancer treatments.

\begin{tabular}{|c|c|c|c|c|c|}
\hline Intervention & Target & Cancer type targeted & Affiliates & Trials stage & Current status \\
\hline $\begin{array}{l}\text { Biological: CD105/Yb-1/ } \\
\text { SOX2/CDH3/MDM2 } \\
\text { multiplasmid vaccine }\end{array}$ & $\begin{array}{l}\text { MDM2- } \\
\text { expressing } \\
\text { tumor cells }\end{array}$ & $\begin{array}{l}\text { Advanced solid tumors, } \\
\text { lymphomas }\end{array}$ & $\begin{array}{l}\text { University of } \\
\text { Washington }\end{array}$ & Phase I & Not yet recruiting \\
\hline Drug: R06839921 & $\begin{array}{l}\text { MDM2-p53 } \\
\text { interaction }\end{array}$ & $\begin{array}{l}\text { Neoplasms, leukemia, } \\
\text { myelodysplastic syndrome }\end{array}$ & $\begin{array}{l}\text { Hoffman-La } \\
\text { Roche }\end{array}$ & Phase I & Recruiting \\
\hline Drug: DS-3032 & $\begin{array}{l}\text { MDM2-p53 } \\
\text { interaction }\end{array}$ & HER2-negative stage III-IV & $\begin{array}{l}\text { Daiichi Sankyo } \\
\text { Inc. }\end{array}$ & Phase I & Recruiting \\
\hline Drug: R05045337 & $\begin{array}{l}\text { MDM2-p53 } \\
\text { interaction }\end{array}$ & $\begin{array}{l}\text { Soft tissue sarcoma, } \\
\text { neoplasms, leukemia }\end{array}$ & $\begin{array}{l}\text { Hoffman-La } \\
\text { Roche }\end{array}$ & Phase Ib & $\begin{array}{l}\text { Active, not recruiting/ } \\
\text { Completed }\end{array}$ \\
\hline Drug: R05503781 & $\begin{array}{l}\text { MDM2-p53 } \\
\text { interaction }\end{array}$ & Neoplasms & $\begin{array}{l}\text { Hoffman-La } \\
\text { Roche }\end{array}$ & Phase I & Completed \\
\hline $\begin{array}{l}\text { Drug: } \\
\text { thioureidobutyronitrile }\end{array}$ & p53 activator & Solid Tumors & $\begin{array}{l}\text { Cellceutix } \\
\text { Corporation }\end{array}$ & Phase I & Recruiting \\
\hline Drug: HDM201 & $\begin{array}{l}\text { MDM2-p53 } \\
\text { interaction }\end{array}$ & $\begin{array}{l}\text { Advanced tumors } \\
\text { (TP53wt) liposarcoma }\end{array}$ & $\begin{array}{l}\text { Novartis } \\
\text { Pharmaceuticals }\end{array}$ & Phase I & Recruiting \\
\hline Drug: CGM097 & $\begin{array}{l}\text { MDM2-p53 } \\
\text { interaction }\end{array}$ & $\begin{array}{l}\text { Solid tumors with p53 wt } \\
\text { states }\end{array}$ & $\begin{array}{l}\text { Novartis } \\
\text { Pharmaceuticals }\end{array}$ & Phase I & Recruiting \\
\hline Drug: SAR405838 & $\begin{array}{l}\text { MDM2-p53 } \\
\text { interaction }\end{array}$ & Neoplasm malignant & Sanofi & Phase I & Ongoing \\
\hline Drug: MK-8242 & $\begin{array}{l}\text { MDM2-p53 } \\
\text { interaction }\end{array}$ & Solid tumors & $\begin{array}{l}\text { Merck Sharp \& } \\
\text { Dohme Corp. }\end{array}$ & Phase I & Completed \\
\hline Drug: AM 232 & $\begin{array}{l}\text { MDM2-p53 } \\
\text { interaction }\end{array}$ & $\begin{array}{l}\text { Advanced solid tumors, } \\
\text { multiple myeloma }\end{array}$ & Amgen & Phase I & Recruiting \\
\hline
\end{tabular}


tumor region and malignant cells. The fact that PSMA is a transmembrane protein is also important, as its extracellular region can be easily targeted by therapeutics. Also, the presence of an internalization sequence within the protein means that therapeutics targeted at PSMA could be internalized through binding. Finally, PSMA's peptidase activities, means that it could be involved in the processing of a pro-drug targeted at tumor cells [36-38]. Therefore, there is a very strong case for the use of PSMA as a biomarker and therapeutic target in the fight against cancer.

\section{PSMA as a biomarker}

Since prostate cancer tissues shows high PSMA expression and increased enzymatic activity of PSMA compared with normal and benign hyperplasia prostate tissues $[39,40]$ the use of PSMA as a biomarker for prostate cancer is under investigation. A direct correlation has been identified in adenocarcinomas between the expression of PSMA and Gleason score, which is used to stage prostate cancer [40]. A study by Ross et al. suggests that PSMA could act as a biomarker for prognosis as it shows a significant correlation with adverse prognostic factors such as tumor grade, aneuploidy, biochemical recurrence and pathological stage [32].

The current standard for early detection of prostate cancer involves a digital rectal examination and a serum test for prostate-specific antigen (PSA). Despite its use, there is no definite level of PSA which can actively distinguish between men with prostate cancer and those with a benign hyperplasia, leading to falsepositive results and overtreatment of men with limited disease [33].

PSMA immunohistochemistry was seen to have a higher $(84 \%)$ sensitivity than PSA (58\%) in staining of tissues from metastatic sites. Strong, diffuse staining was seen in 17 of 19 cases of metastatic prostate cancers, compared with 13 from PSA staining. Positivity for either of the molecules was seen in $89 \%$ of metastatic prostate cancer and this combination immunohistochemistry was slightly more sensitive than that of PSMA alone, indicating that a combination of PSMA and PSA immunohistochemistry could be a beneficial prognostic assessment for patients [41].

Quantification of PSMA and PSA levels in peripheral blood showed significant differences among $\mathrm{BPH}$, locally confined prostate cancer and metastasized prostate cancer in expression of PSA and PSMA. It was found that one cancer cell could be detected in $2 \times 10^{7}$ mononuclear cells [42].

The first clinical agent targeting PSMA in prostate cancer was the monoclonal antibody 7E11/CYT-356, which was labeled with Indium-111 and known as ${ }^{111}$ In-capromab or ProstaScint $[30,43,44]$. The sensitivity and specificity of the antibody has differed in studies, with an average sensitivity of $60 \%$, a specificity of $70 \%$, a positive predictive value of $60 \%$ and a negative predictive value of $70 \%[45,46]$. These poor results could be a consequence of ${ }^{111} \mathrm{In}$-capromab recognizing an intracellular epitope, and therefore only binding molecules in cells with a damaged cell membrane [30].

This led to the development of second-generation antibodies which can bind to the extracellular region of PSMA and thus could be superior to the capromab pendetide. One of these developed antibodies, J591, has shown potential in imaging primary prostate cancer, as well as bone metastases. Clinical trials with ${ }^{99 \mathrm{~m}} \mathrm{Tc}$-labeled J591 established detection of primary prostate cancer, as well as prostate bed recurrence and distant metastases, again, including metastasis to bone $[30,47]$. Several other developed monoclonal antibodies (3/A12, 3/E7 and 3/F11) bind to different epitopes of PSMA [35]. A study using ${ }^{64} \mathrm{Cu}-3 / \mathrm{A} 12$ for PET imaging of prostate cancer xenograft showed a good tumor-to-background ratio [44]. A fourth monoclonal antibody targeting PSMA, 3C6, has been labeled with ${ }^{111}$ In for imaging in prostate cancer [48].

Radiolabeled PSMA inhibitor N-[N-[-(S)-1,3-dicarboxypropyl $]$ carbamoyl $]-S-\left[{ }^{11} \mathrm{C}\right]$ methyl-l-cysteine (DCFBC) has been successfully used in PET imaging of xenografts expressing PSMA [49]. The molecule was labeled with ${ }^{18} \mathrm{~F}$, with studies into its biodistribution and imaging showing a high uptake of ${ }^{18} \mathrm{~F}$-DCFBC in PSMA-positive tumors but slight or no uptake in tumors negative for PSMA [50]. Urea-based compounds have also been identified as possible targets for imaging of prostate cancer with PET and SPECT [51]. MIP-1095 and MIP-1072, which are small-molecule inhibitors targeting PSMA, have shown a high affinity for PSMA and their uptake when labeled with ${ }^{123}$ I has been successfully imaged by SPECT [52,53].

\section{PSMA as a therapeutic target}

PSMA has been exposed as an attractive therapeutic target due to its expression being 100- to 1000-fold less in normal cells in comparison to prostate carcinoma cells [54]. So far, antibody-based radiotherapy, antibody-drug conjugates (ADC), PSMA-targeted prodrug therapy and PSMA-based immunotherapy have been investigated [30].

The leading PSMA antibody-based radiotherapeutic is Lutetium-177 J591, which showed acceptable toxicity and excellent metastatic site targeting in a Phase I clinical trial [55]. A recent Phase II clinical trial utilized Lutetium-177 J591 in patients with metastatic castration-resistant prostate cancer [56]. Just less than $60 \%$ of patients showed a decrease in PSA levels with $1 / 10$ showing a reduction of more than half and the 


\begin{tabular}{|c|c|c|c|c|c|}
\hline Intervention & Use & $\begin{array}{l}\text { Cancer type } \\
\text { targeted }\end{array}$ & Affiliates & Trials stage & Current status \\
\hline Drug: 68Ga-PSMA & Imaging/diagnosis & Prostate cancer & Ebrahim Delpassand & Phase II & Recruiting \\
\hline Drug: PSMA ADC 2301 & Treatment & mCRPC & $\begin{array}{l}\text { Progenics } \\
\text { Pharmaceuticals, Inc. }\end{array}$ & Phase II & Completed \\
\hline Drug: PSMA ADC BrUOG 263 & Treatment & $\begin{array}{l}\text { Glioblastoma } \\
\text { multiforme, } \\
\text { gliosarcoma }\end{array}$ & Heinrich Elinzano, MD & Phase II & $\begin{array}{l}\text { Active, not } \\
\text { recruiting }\end{array}$ \\
\hline Drug: PSMA ADC 1301 & Treatment & $\mathrm{mCRPC}$ & $\begin{array}{l}\text { Progenics } \\
\text { Pharmaceuticals, Inc. }\end{array}$ & Phase I & Completed \\
\hline $\begin{array}{l}\text { Biological: peptide vaccine/ } \\
\text { drug: poly IC-LC }\end{array}$ & Vaccine treatment & Prostate cancer & $\begin{array}{l}\text { H. Lee Moffitt Cancer } \\
\text { Center and Research } \\
\text { Institute }\end{array}$ & Phase I & $\begin{array}{l}\text { Active, not } \\
\text { recruiting } \\
\text { (has results) }\end{array}$ \\
\hline $\begin{array}{l}\text { Drug: Anti-PSMA designer } \\
\text { T cells }\end{array}$ & Treatment & Prostate cancer & $\begin{array}{l}\text { Roger Williams Medical } \\
\text { Centre }\end{array}$ & Phase II & $\begin{array}{l}\text { Active, not } \\
\text { recruiting }\end{array}$ \\
\hline $\begin{array}{l}\text { Biological: rsPSMA protein } \\
\text { plus alhydrogel vaccine }\end{array}$ & Vaccine treatment & Prostate cancer & $\begin{array}{l}\text { Memorial Sloan- } \\
\text { Kettering Cancer Centre }\end{array}$ & Phase I & Completed \\
\hline $\begin{array}{l}\text { Biological: anti-PSMA } \\
\text { monoclonal antibody } \\
\text { MDX1201-A488 }\end{array}$ & Imaging/diagnosis & Prostate cancer & $\begin{array}{l}\text { City of Hope Medical } \\
\text { Centre }\end{array}$ & Phase I & Recruiting \\
\hline $\begin{array}{l}\text { Biological: gene modified T } \\
\text { cells }\end{array}$ & Treatment & Prostate cancer & $\begin{array}{l}\text { Roger Williams Medical } \\
\text { Centre }\end{array}$ & Phase I & $\begin{array}{l}\text { Active, not } \\
\text { recruiting }\end{array}$ \\
\hline $\begin{array}{l}\text { Biological: engineered } \\
\text { autologous T cells/drug: } \\
\text { cyclophosphamide }\end{array}$ & Treatment & Prostate cancer & $\begin{array}{l}\text { Memorial Sloan- } \\
\text { Kettering Cancer Centre }\end{array}$ & Phase I & Recruiting \\
\hline $\begin{array}{l}\text { Biological: human PSMA } \\
\text { plasmid DNA vaccine }\end{array}$ & Treatment & Kidneycancer & $\begin{array}{l}\text { Memorial Sloan- } \\
\text { Kettering Cancer Centre }\end{array}$ & Phase I & $\begin{array}{l}\text { Active, not } \\
\text { recruiting }\end{array}$ \\
\hline Drug: 18F-DCFBC & Imaging/diagnosis & Prostate cancer & $\begin{array}{l}\text { Sidney Kimmel } \\
\text { Comprehensive Cancer } \\
\text { Center }\end{array}$ & Phase II & $\begin{array}{l}\text { Active, not } \\
\text { recruiting }\end{array}$ \\
\hline $\begin{array}{l}\text { Device: ProxiScan } \\
\text { (scintigraphic rectal probe) }\end{array}$ & Imaging/diagnosis & Prostate cancer & $\begin{array}{l}\text { Sidney Kimmel } \\
\text { Comprehensive Cancer } \\
\text { Center }\end{array}$ & Phase I & Completed \\
\hline $\begin{array}{l}\text { Biological: PSMA prostate } \\
\text { cancer vaccine/IL-12 }\end{array}$ & Treatment & Prostate cancer & University of Chicago & Phase II & Completed \\
\hline $\begin{array}{l}\text { Biological: PSMA/PRAME } \\
\text { (MKC1106-PP) }\end{array}$ & Treatment & $\begin{array}{l}\text { Advanced } \\
\text { cancer }\end{array}$ & Mannkind Corporation & Phase I & Completed \\
\hline Drug: 123I-MIP-1072 & Imaging/diagnosis & Prostate cancer & $\begin{array}{l}\text { Molecular Insight } \\
\text { Pharmaceuticals, Inc. }\end{array}$ & Phase I & Terminated \\
\hline Drug: 89Zr-J591 & Imaging/diagnosis & $\begin{array}{l}\text { Glioblastoma } \\
\text { multiforme, } \\
\text { gliosarcoma }\end{array}$ & $\begin{array}{l}\text { Memorial Sloan- } \\
\text { Kettering Cancer Centre }\end{array}$ & Phase I & Recruiting \\
\hline $\begin{array}{l}\text { Drug: } 111-\text { In capromab } \\
\text { pendetide }\end{array}$ & Imaging/diagnosis & Prostate cancer & $\begin{array}{l}\text { Molecular Insight } \\
\text { Pharmaceuticals, Inc. }\end{array}$ & Phase I & Completed \\
\hline $\begin{array}{l}\text { Biological: androgen } \\
\text { ablation/dendritic cell } \\
\text { vaccine }\end{array}$ & Treatment & Prostate cancer & Pawel Kanlinkski & Phase I & Recruiting \\
\hline Drug: 89Zr-DFO-huJ591 & Imaging/diagnosis & Prostate cancer & $\begin{array}{l}\text { Memorial Sloan- } \\
\text { Kettering Cancer Centre }\end{array}$ & Phase II & $\begin{array}{l}\text { Active, not } \\
\text { recruiting }\end{array}$ \\
\hline
\end{tabular}


Table 2. Clinical trials utilizing prostate-specific membrane antigen for cancer imaging and treatments (cont.).

\begin{tabular}{|c|c|c|c|c|c|}
\hline Intervention & Use & $\begin{array}{l}\text { Cancer type } \\
\text { targeted }\end{array}$ & Affiliates & Trials stage & Current status \\
\hline Drug: G-202 & Imaging/diagnosis & $\begin{array}{l}\text { Glioblastoma } \\
\text { multiforme, } \\
\text { advanced } \\
\text { hepatocellular } \\
\text { carcioma }\end{array}$ & GenSpera, Inc. & Phase II & $\begin{array}{l}\text { Recruiting } \\
\text { Phase II }\end{array}$ \\
\hline Radiation: [ $\left.{ }^{89} \mathrm{Zr}\right] \mathrm{Df}-\mathrm{IAB} 2 \mathrm{M}$ & Treatment & Prostate cancer & Imagin $A b$, Inc. & Phase II & Recruiting \\
\hline Drug: EC1169 & Treatment & Prostate cancer & Endocyte & Phase I & Recruiting \\
\hline Drug: GVAX and ipilimumab & Treatment & $\mathrm{mCRPC}$ & $\begin{array}{l}\text { VU University Medical } \\
\text { Center }\end{array}$ & Phase I & Terminated \\
\hline
\end{tabular}

therapeutic showed accurate targeting of metastatic sites [38]. The higher concentration used in the trials $\left(70 \mathrm{mCi} / \mathrm{m}^{2}\right)$ led to longer survival of patients (almost 22 months, compared with 12 months), but resulted in increased grade 4 hematologic toxicity and platelet transfusions [30,56].

J591 antibody has also been utilized in the production of ADC, which involves the linking of a drug or toxin to an antibody [38]. MLN2704 is an antimicrotubule agent which has been conjugated to J591. Phase I studies in over 20 patients showed PSA levels dropped by more than half in two patients, although grade 3 toxicities occurred in three of the patients [30,57]. A multicentre Phase II/III clinical trial undertaken in 62 men with metastatic castration-resistant prostate cancer showed stabilization or decline in PSA in a majority of patients; however, limitation of treatment occurred due to toxic effects of the compound [30,38].

Work has been undertaken in xenograft LNCaP mice, using an immunotoxin consisting of the antiPSA mAb E6 and deglycosylated ricin A, showing reduced tumor growth $[38,58]$. Another group coupled melitten-like peptide 101 to J591 and also saw a significant tumor growth inhibition in mice [38,59]. Monomethylauristatin E (MMAE) has also been conjugated to a $\mathrm{mAb}$ which recognized the PSMA external domain [60].

Recently, a group engineered a prodrug for tumor endothelial cells in prostate cancer therapy [61]. Their work involved the coupling of a PSMA-specific peptide to thapsigargin (inhibitor) of the sarcoplasmic/ endoplasmic reticulum calcium adenosine triphosphate (SERCA) pump. SERCA is a vital cellular protein which is essential for the viability of all cell types. Before cleavage of the PSMA-specific molecule, the conjugate is inactive. However, post-cleavage, local
SERCA inhibition ensues [30]. Preclinical xenograft models treated with thapsigargin showed significant prostate cancer tumor regression at doses which were modestly toxic to the host [61].

The use of immunotherapy in oncology has been long utilized, but only recently has work on PSMA as a target begun to be investigated [38]. This type of therapy is based on the concept that IL-2 stimulates natural killer cells, thus enhancing antibody-dependent cellular cytotoxicity. A Phase II trial of the antiPSMA monoclonal antibody J591 was undertaken in patients with recurrent prostate cancer for 8 weeks, with patients receiving continuous low-dose subcutaneous IL-2 every day, with infusions of J591 weekly. Of 17 patients, nine had stable PSA, with declines of up to $34 \%$. The therapy was well tolerated and the toxicity was low, with non-progressors showing a trend with significant natural killer (NK) cell expansion [30,38,62].

Thus, although PSMA-targeted therapy is yet to yield clinically important effects on the survival of patients without severe side effects ensuing, several fields are currently under study and as our molecular techniques and our understanding of tumor biology become more advanced, PSMA-therapeutics are likely to play an important role in the development of treatment for cancer patients [30] (clinical trials of PSMA as a biomarker and therapeutic target summarized in Table 2 [63]).

\section{Tumor-associated angiogenesis mediated by MDM2 \& PSMA}

Vascular endothelial factor (VEGF) is a potent angiogenic factor that plays an important role in regulating normal physiological and pathological angiogenesis. Correctly timed expression of VEGF at appropriate levels is crucial for normal development of vascula- 
ture and homeostasis, but also vital for solid tumor growth. VEGF is highly expressed in solid tumors and is required for the development and maintenance of blood vessels within the tumor, which is a prerequisite for successful tumor growth and metastasis.

A co-expression study was undertaken to evaluate the correlated expression of MDM2 and VEGF, finding that, over eight different cancer cell lines, higher MDM2 expression meant higher VEGF mRNA, with the cell lines with lost p53 function showing highest VEGF levels [64]. They verified their findings further by inhibiting MDM2 using a specific MDM2-specific antisense oligonucleotide (HDMAS5) and saw a significant decrease in VEGF mRNA and protein levels. Finally, they proved that transfecting the MDM2 gene in the prostate cancer cell line, LNCaP, produced a cell line overexpressing MDM2 and VEGF. The same group then identified MDM2 as a regulator of VEGF expression in cancer cells. HUVECs were treated with tumor-conditioned media from HMAS5-treated cancer cells. They found that VEGF release from cells and VEGF-dependent angiogenesis were significantly reduced in vitro [65].

Hypoxia-inducible factor 1 (HIF-1) is a heterodimeric transcription factor which generates a response to oxygen deprivation due to hypoxic conditions. Active HIF-1 is comprised of two subunits: HIF-1 $\beta$ is constitutively expressed in the cell, however, under normoxic conditions HIF- $1 \alpha$ is covalently modified by prolyl hydroxylases, allowing VHL E3 ubiquitin ligase to polyubiquitinate and thus targets HIF- $1 \alpha$ for degradation [66,67]. Factor inhibiting HIF-1 (FIH-1) can also hydroxylate HIF-1 $\alpha$, preventing coactivator binding and so inhibiting transcription of target genes [68]. Following a decrease in cellular oxygen levels, the rates of hydroxylation are decreased, VHL does not bind, HIF- $1 \alpha$ is stabilized and the HIF-1 the heterodimer can form [69]. Overexpression of HIF-1 $\alpha$ has been linked to angiogenesis, tumor invasion and a poor prognosis in many types of cancer [70-73]. The HIF-1 transcription factor binds to the 5 ' flanking sequence of vegf and is essential for the transactivation of vegf during hypoxia (see Figure 2).

It has been known for some time that hypoxia is a physiological inducer of tumor suppressor $\mathrm{p} 53$, with p53 protein levels increasing under hypoxic conditions [74]. Since MDM2 is the most important negative regulator of $\mathrm{p} 53$, many groups began to look into the precise mechanism of the interaction between hypoxia and $\mathrm{p} 53$, and whether MDM2 was involved [68,75-84].

In 2005, a study showed that MDM2 positively activates HIF-1 $\alpha$ in hypoxic tumor cells. Co-immunoprecipitation showed that MDM2 precipitates with HIF-1 $\alpha$, completely independently of p53 [75].
Evidence toward the involvement of MDM2 in the regulation HIF-1 $\alpha$ expression under hypoxic conditions came from Lau et al. [76], who found that inhibitory effects on HIF- $1 \alpha$ by the anti-cancer drug 3-(5'-hydroxymethyl-2'-furyl)-1-benzyl indazole (YC1), was MDM2-dependent and that overexpression of MDM2 reversed its inhibitory effects. A very recent study also suggested that, under hypoxic conditions, MDM2 is capable of ubiquitinating HIF- $1 \alpha$ with its E3 ubiquitin ligase domain in a PTEN/PI3K-dependent manner. The group's results suggested that the PI3K-AKT signaling axis is a requirement for the preservation of HIF-1 $\alpha$ stability during hypoxia [69] (see Figure 2).

Another study showed that nutlin-3 conferred antiangiogenic activity. It was found that nutlin-3 dosedependently suppressed the total tube length and the number of capillary connections developed from HUVECs. Also, the migration of endothelial cells was shown to be significantly inhibited by nutlin-3 in response to various chemoattractants [77]. In the same year, two more reports were published demonstrating the inhibition of HIF-1 $\alpha$ by nutlin-3, leading to inhibited VEGF production and thus angiogenesis in tumors [78,79]. Lee et al. [80] then suggested a mechanism through which this occurred after finding that nutlin-3 downregulated HIF-1 $\alpha$ in p53-positive cells but also functionally inactivated HIF- $1 \alpha$ in p 53 -negative cells. Of these two occurrences, they found that the second mainly contributed to VEGF suppression by nutlin-3. It was reported that MDM2 competes with FIH which is a regulator of HIF-1 $\alpha$, by binding its C-terminal transactivation domain (CAD). FIH hydroxylates Asn803 in the CAD domain under normoxic conditions. However, when conditions are hypoxic, this hydroxylation is inhibited due to the limited oxygen and so HIF-1 $\alpha$ becomes stable and active [68,81]. When MDM2 competes for binding of the CAD of HIF-1 $\alpha$, this hydroxylation is inhibited and so p300 is recruited. They found that nutlin-3 reinforced the FIH-mediated inactivation of HIF-1 $\alpha$ through inhibiting any interaction between CAD and MDM2 [80]. This theory is in direct contrast to the report by LaRusch et al. [78], who reported that the N-terminal domain of HIF-1 $\alpha$ was needed for binding of MDM2. This could imply that each domain of HIF-1 $\alpha$ interacts individually in different ways with MDM2 or they cooperate to bind MDM2.

Therefore, it is widely accepted that hypoxia induces VEGF transcription through induction of HIF-1 $\alpha$. However, in 2011, a group set out to investigate the posttranscriptional regulation occurring, in which HIF-1 $\alpha$ does not seem to be important [82]. Their work followed on from a study which showed that in rat cardiac myo- 


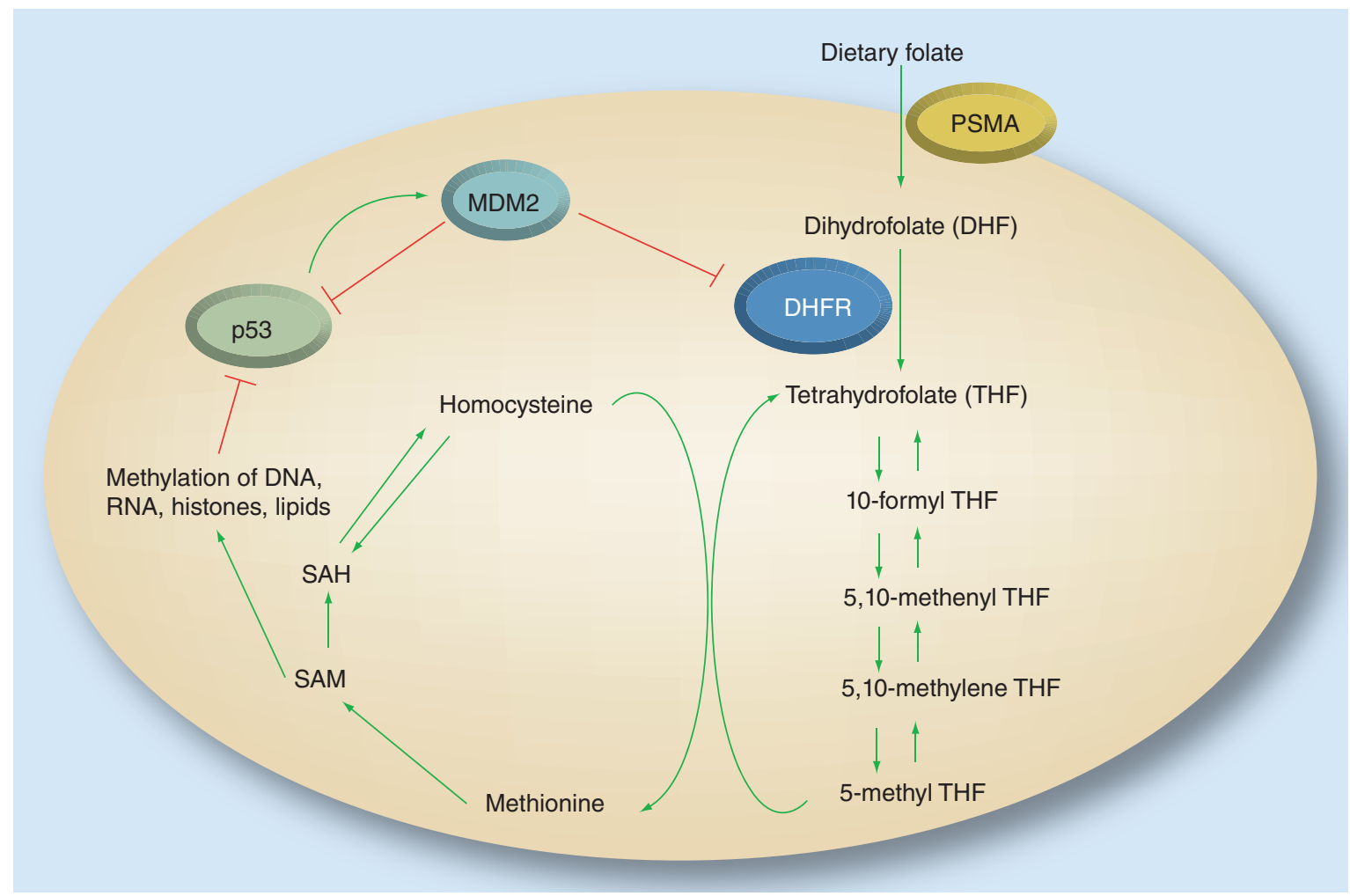

Figure 1. Hypothesized mouse double minute 2 and prostate-specific membrane antigen interaction through folate metabolism in aggressive tumors. PSMA metabolizes dietary folate to produce dihydrofolate, which is then converted to tetrahydrofolate by DHFR. DHFR is regulated by MDM2 through its RING-finger dependent E3 ligase activity, which is known to also regulate the p53 tumor suppressor. The p53 tumor suppressor is regulated by methylation of DNA, RNA, histones and lipids, which is governed by folate metabolism. Therefore, we hypothesize that in cancer cells, PSMA may be involved in the expression or activity of MDM2 through aberrant regulation of p53 methylation via folate metabolism.

cytes hypoxia can induce VEGF steady-state mRNA 25-fold; however, the hypoxia-mediated transcription rate of VEGF increases just 3.1-fold [85]. Their results showed that the RING domain of MDM2 can bind to AU-rich elements of the VEGF 3' untranslated region (UTR) and regulate VEGF mRNA stability and thus its translation. Interestingly, they also demonstrated that during hypoxia, MDM2 was dephosphorylated and translocated to the cytoplasm from the nucleus, where it was able to induce high levels of VEGF in cancer cells [82]. The same group then undertook a study to elucidate whether p53 played a role in the interaction between MDM2 and VEGF. They did this through the use of two cell lines, MCF-7 which expresses wild-type p53 and MDA-MB-468, which expresses mutant p53. They studied the effect of nutlin-3 and anti-MDM2 antisense oligonucleotide (ASO), on these cell lines and saw that ASO significantly inhibited the VEGF transcript and protein levels in a dose- and time-dependent manner, whereas nutlin-3 had no effect. The effect of hypoxia was also studied, and it was observed that ASO treatment significantly inhibited HIF-1 $\alpha$ expression at 3, 6 and $12 \mathrm{~h}$ of hypoxia in both cell lines. An inhibitory effect on HIF-1 $\alpha$ was also seen in the nutlin-3 treated MCF-7 (wild-type p53) but not in MDAMB-468 (mutant p53). The group used siRNA targeted at HIF-1 $\alpha$ as well as ASO treatment, and found that HIF- $1 \alpha$ only seems to have a role in VEGF production in early hypoxia (at $6 \mathrm{~h}$, but not at $48 \mathrm{~h}$ ). HIF-1 $\alpha$ siRNA did not reverse the inhibitory effect of ASO on VEGF production. Therefore, the group surmised that ASO downregulates hypoxia-induced VEGF production via a HIF-1 $\alpha$-independent mechanism. When the same experiment was undertaken using nutlin-3, it was seen that nutlin-3 significantly inhibited the level of secreted VEGF from the MCF-7 cells at early hypoxia. When the cells were transfected with HIF-1 $\alpha$ siRNA, nutlin-3 failed to inhibit VEGF production. This exhibits that the effect of nutlin-3 on VEGF regulation in early hypoxia is HIF- $1 \alpha$-dependent. ASO treatment of mice with tumors of each cell type showed a substantial decrease in serum VEGF levels, measured by ELISA. On the other hand, nutlin-3 treatment produced little effect on VEGF production [83].

A very recent study investigated the precise mechanism supporting the induction of VEGF transcrip- 


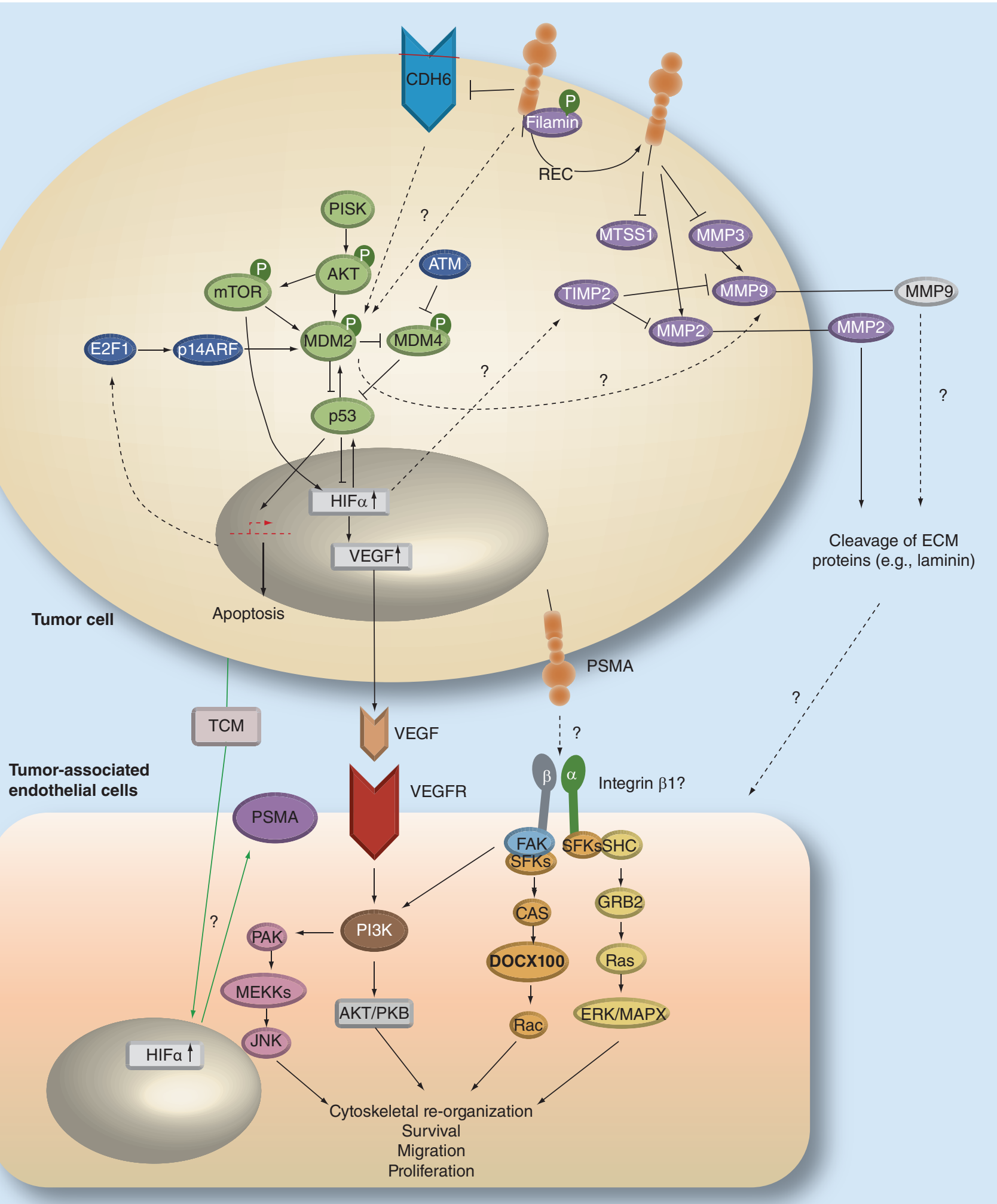

Figure 2. Proposed interplay roles of mouse double minute 2 and prostate-specific membrane antigen in tumor invasion through multiple signaling pathways. MDM2 and PSMA have both been linked to MMP-2 and MMP-9. HIF-1 $\alpha$ is known to regulate the MMP inhibitor, TIMP-1. Since MDM2 activates HIF-1 $\alpha$, both PSMA and MDM2 could play a role in MMP regulation during hypoxia. MDM2 inactives p53 which is known suppress transcription of VEGF. The P13K and PAK pathways in endothelial cells can be activated directly by VEGF and also indirectly by PSMA through binding with integrin. Therefore MDM2 and PSMA may mediate angiogenesis which could permit the exertion of a synergetic pro-angiogenic effect between the proteins. 
tion by MDM2. They used prostate cancer cell lines LNCaP and MDM2 transfected LNCaP (LNCaPMST). As expected, they found that VEGF transcription was significantly higher in the LNCaP-MST cells compared with the nontransfected LNCaP [84]. Activation of the PI3K-mTOR pathway has previously been reported upon increase of VEGF expression in normoxic and hypoxic conditions [65]. Since HIF-1 $\alpha$ is required as a primary member of this pathway, it is generally assumed that activation of the pathway is more effective under hypoxic conditions, in terms of induction of VEGF transcription. Yet, this study showed that in the LNCaP-MST cells, the PI3KmTOR pathway seems to be activated and the basal HIF-1 $\alpha$ appear high. They reported that MDM2 seemed to be triggering an elevated level of HIF- $1 \alpha$, in line with increasing expression of VEGF in normoxic cells, even when hypoxic conditions are lacking. The data presented also suggested that STAT3 and NF- $\mathrm{KB}$ may play important roles in MDM2-mediated activation of VEGF transcription, since their levels were increased in the LNCaP-MST cells compared with the nontransfected LNCaP cells [84].

It has also been suggested that p 53 can negatively regulate VEGF expression. In 2000, Ravi et al. [86] claimed that homozygous deletion of p53 in human colon cancer cells promoted neovascularization and growth of xenograft tumors in nude mice. They showed that upon loss of $\mathrm{p} 53$, HIF-1 protein levels are enhanced and so VEGF expression is augmented. It was also demonstrated that forced HIF-1 $\alpha$ expression in p53-expressing cancer cells promotes the expression of VEGF and this leads to neovascularization of tumor xenografts. Therefore, the group concluded that p53 acts as a molecular chaperone to HIF- $1 \alpha$, facilitating its recognition by MDM2 for ubiquitination. This work was disputed by a later study [75] which suggests that the group's results may be due to the use of hypoxia-mimicking agents such as cobalt and thus the proteins in complex could change.

In conclusion, despite the great amount of studies undertaken in order to elucidate the role of MDM2 in both angiogenesis and hypoxia, the precise mechanisms are yet to be exposed. It is widely accepted that MDM2 and VEGF levels are coordinated in cancer and that HIF-1 $\alpha$ increase can upregulate VEGF transcription during hypoxia. It has been proved many times that MDM2 and HIF- $1 \alpha$ interact during hypoxia, although whether this is a direct or indirect interaction, and whether it involves $\mathrm{p} 53$ tumor suppressor is under scrutiny. It has also been suggested that a second layer of regulation occurs between MDM 2 and VEGF, at posttranscriptional level, independent of HIF-1 $\alpha$. Therefore, perhaps there are different points of regulation of
VEGF levels by MDM2 during hypoxia and HIF-1 $\alpha$ and p53 may play a role in some, but not others.

In terms of links of PSMA to VEGF, there are differing reports. A report by Tsui et al. [87] claimed that there was a correlation between PSMA and VEGF expression in the tumors of xenograft mice, when immunohistological analysis was undertaken. Forced PSMA expression in a prostate cancer cell line, RM-1 and quantification of secretion of VEGF by cells, led to the conclusion that stable transfection of PSMA promoted VEGF release. When these cells were injected into mice, immunohistochemistry was performed and VEGF levels were seen to be significantly higher in the mice injected with the cells expressing PSMA [88].

Since it is found in the neovasculature of many tumors, PSMA is thought to regulate angiogenesis. In 2006, a group demonstrated that PSMA is required for angiogenesis in vivo and invasion of endothelial cells in vitro, where it was exhibited to be involved in laminin-specific signaling and regulation of the dynamics of the cytoskeleton through the Rho GTPase effector molecule p21-activated kinase 1 (PAK-1). The group hypothesised that PSMA partakes in an autoregulatory feedback loop where, in its active state, it increases integrin signal transduction, PAK activation, followed by endothelial cell adhesion and invasion. This process leads to the dissociation the PSMA/filamin complex and a decrease in PSMA activity and therefore integrin- $\beta 1$ activity is held in check [89] (see Figure 2).

In a subsequent study, the same group then went on to assess the role of PSMA in ocular neovascularization. To do this they used an oxygen induced retinopathy model (OIR) and it was observed that, after an initial decrease in retinal PSMA mRNA, transcript levels were progressively increased over the time of the relative hypoxia. Vessel formation was then assessed in the retina of PSMA null mice under these conditions of relative hypoxia. Again, it was seen that the loss of PSMA in these mice did not affect the development of normal retinal vasculature. However, mice undergoing OIR showed a remarkable difference between PSMA null and wild-type. The capillaries in the midperiphery formed a dense, honeycomb of close vessels. In comparison, retinas from PSMA null animals after OIR showed a vascular pattern which closely resembled the normal structure, with less avascular area in the central region and more highly branched capillaries in the periphery. It was also seen that, in comparison to the wild-type, PSMA null mice vessels were better perfused and more functional. Finally, the study evaluated the use of 2-(phosphonomethyl)pentanedioic acid (2-PMPA) PSMA inhibitor in wild-type mice and obtained similar results. Therefore, the absence of 
PSMA seems to lead to a less pathogenic phenotype in the retina. The involvement of PSMA in angiogenesis through this mechanism was seen to be independent of VEGF [90].

It is certain that PSMA is involved in angiogenesis; however, the precise mechanism by which PSMA exerts its effect is unknown. PSMA has been linked to VEGF levels in some reports, with increased and decreased PSMA levels being reflected in VEGF expression. However, a group who have released a number of related papers on the subject of PSMA in angiogenesis claim that the involvement of this protein is VEGF-independent. This suggests that PSMA may also play a number of roles in angiogenesis, some involving VEGF, others not.

\section{Participation of MDM2 \& PSMA in tumor invasion \& metastasis}

Due to the high expression of PSMA and MDM2 a number of cancer types, their roles in the invasion and subsequent metastasis of tumors have been studied. Migration and invasion through the extracellular matrix are reliant on the matrix metalloproteinases (MMPs) which are zinc-dependent remodeling endopeptidases implicated in many pivotal roles in tumor growth and the multistep processes of invasion and metastasis. Different members of the MMP family exert contradicting roles at various stages of cancer progression [91].

The most obvious feature of MDM2 involvement in the progressive properties of cancer is its interaction with $\mathrm{p} 53$. The ability of MDM2 to block p53 activity is exploited by tumor cells. However, there are other ways in which MDM2 contributes to the progression of cancer. It was shown that in breast cancer cells MDM2 can decrease E-cadherin protein level through ubiquitination and ectopic expression of MDM2 increases cell-cell dissociation, invasion and cell motility [92]. A study into patients with malignant melanoma showed that MDM2 expression level was directly associated with the thickness of a tumor and weakly with invasion level [93].

Immunohistochemical staining of invasive ductal breast carcinoma (IDC) showed a significant correlation between MDM2 and MMP-9 expression. In vitro studies in MDA-MB-231 and MCF-7 breast cancer cell lines have shown that siRNA targeted at MDM2targeted siRNA significantly decreased cell invasion, migration and proteolysis, with the opposite seen in cells overexpressing MDM2. MDM2 overexpression in these cells was seen to induce MMP-9 expression in a dose-dependent manner [94]. A slightly later study also linked the expression of MDM2 and MMP-9 in the oncogenesis of lung cancer in rats [95] (see Figure 2).
A paper by Ghosh et al. [96] showed that, surprisingly, in prostate cancer cells, ectopic expression of PSMA in the PSMA-negative cell line PC-3 cells reduced their invasiveness. On the other hand, they found that knockdown of PSMA in the PSMA-positive cell line, LNCaP, increased their invasiveness fivefold. PSMA mutants lacking the carboxypeptidase activity of the protein were produced and showed that this reduced the impact of PSMA expression on invasiveness. Another study involving the injection of the mouse prostate cancer cell line RM-1 with stable expression of PSMA into mice showed the formation of lytic bone lesions and distinct MMP-9 expression compared with the control [88].

Recently, it was found that the sequential digestion of laminin, a predominant component of the extracellular matrix (ECM), occurs through PSMA working downstream of MMP-2, generating small peptides which enhance the invasive and adhesive abilities of HUVECs in vitro, providing evidence that these peptides activate adhesion through integrin $\alpha_{6} \beta_{1}$ and FAK. It was suggested that since PSMA is a glutamatespecific peptidase, cleavage of a laminin-derived peptide substrate could modify the overall charge of the peptide and so facilitate integrin binding [97].

Another study has linked the expression levels of PSMA and MDM2 in no uncertain terms. LNCaP (PSMA positive) and PC3 (PSMA negative) cell lines were used to assess metastasis-related genes which were downregulated in cells with silenced PSMA. It was found that MDM2 transcript levels were decreased over 80-fold following PSMA silencing. This paper also indicated that the treatment of the LNCaP cell line with PSMA-targeted siRNA led to an upregulation of MMP-3 and -13, and a downregulation of MMP-2 [98] (see Figure 2). This decrease has also been shown in breast cancer cell lines in our own laboratory (unpublished data). Since the degradation of the extracellular matrix and basement membrane by MMPs is pivotal to whether a tumor infiltrates and metastasises, it may be deduced that PSMA could interplay with MDM2 to regulate MMP secretion. This theory is supported by the many reports linking both proteins to a number of MMPs.

In conclusion, if $\mathrm{Xu}$ et al. [98] and our own findings concerning the correlated expression of MDM2 and PSMA are correct, it seems that conflicting data exists regarding invasion capacity as a result of MDM2 and PSMA knockdown and overexpression. Ghosh et al. [96], claimed that PSMA increase reduced in vitro invasion of prostate cancer cell lines, and vice versa; however, Chen et al. [94] saw that MDM2 decrease caused a decrease in invasion, and vice versa, in breast cancer cell lines. Since both proteins have been reported 
to have correlations with MMP-9 [88,94,95] and PSMA has been linked to MMP-2 [97,98], it would be expected that a decrease in transwell cellular invasion would be seen. This apparent contradiction of results could be explained by the fact that different cell lines were used for each study, and these cancer cells were derived from very different areas of the human body (prostate and breast). However, it could also be the result of both proteins being decreased in expression when PSMA levels are decreased, and only MDM2 protein being decreased when the $m d m 2$ gene is targeted, as so far no studies have been published which show the expression levels of PSMA when the $m d m 2$ gene is knocked down. Therefore, the difference in results seen could highlight the pathways in which MDM2 and PSMA interact, and those in which MDM2 works alone. This may mean that when PSMA levels are decreased, factors that increase invasion are produced in the cells and this is a stronger force than those factors that are decreased when MDM2 levels are reduced, which would otherwise decrease invasion. Further work in our own and other laboratories will hopefully lead to an explanation regarding whether this is the case.

\section{Signaling pathways of MDM2 \& PSMA are intertwined by DHFR \& HIF1 $\alpha$}

As aforementioned, PSMA was originally identified as FOLH1, named for its important role in folate metabolism. Previously cited studies show that PSMA plays a critical role in the progressive properties of cancer. It has been found that PSMA expression gives LNCaP prostate cancer cells a growth advantage in media containing low $(<1 \mathrm{nM})$ and physiological $(25 \mathrm{nM})$ folate [99]. The same group then showed that PSMAexpressing PC-3 cells showed a growth advantage compared with wild-type PC-3 cells.

MDM2 has also been identified to have an involvement in folate metabolism, with its ability to directly bind to DHFR and catalyze the monoubiquitination of DHFR via its E3 ubiquitin ligase activity and reduce DHFR activity within cells, without changing levels of steady-state DHFR, in a RING finger-dependent and p53-independent manner [100]. DHFR is an important folate metabolizing enzyme which reduces dihydrofolic acid (DHF) to tetrahydrofolic acid, using NAPDH as an electron donor. Tetrahydrofolic acid can then be converted to many types of tetrahydrofolate cofactors using in one-carbon chemistry. This one-carbon transfer reaction catalyzed by DHFR is essential for DNA synthesis and homocysteine remethylation [101]. Changes in the level of DHFR expression and activity due to genetic polymorphisms can affect a patient's susceptibility to a variety of diseases including cancer. Likewise, variability in DHFR expression can affect the sensitivity of a patient to anticancer drugs such as folate antagonist methotrexate (MTX) [102].

There are two possible mechanisms which could explain the role of folate in tumor development and metastasis. First, folate deficiency causes a reduction of intracellular S-adenosylmethionine (SAM) and therefore can alter cytosine methylation in DNA, leading to an inappropriate activation of proto-oncogenes and induction of malignant [103]. Second, folate deficiency could cause an imbalance of DNA precursors, uracil misincorporation into DNA and chromosome breakage. A further link of MDM2 to folate metabolism is given in the demonstration that folate deficiencies induce DNA strand breaks and hypomethylation within the p53 tumor suppressor gene in animal models, suggesting that the relevance of folate activity stress to carcinogenesis could be p53-dependent [104]. Therefore, the involvement of both MDM2 and PSMA in folate metabolism could provide reasoning for their important role in cancer progression and their possible interplay, since the roles of the two are so closely connected within the pathway.

We hypothesize that in cancer cells, PSMA may be involved in the expression or activity of MDM2 through aberrant regulation of $\mathrm{p} 53$ methylation via its activity in folate metabolism Though this hypothesis needs to be fully investigated, it is partially supported by a recent microarray analysis previously mentioned, which suggests that silencing of PSMA using siRNA leads to downregulation of MDM2 expression [98]. Work by Yao et al. [99] also supports this theory, with their studies showing that increased PSMA expression in conditions of low or physiological folate leads to a growth advantage of prostate cancer cell lines. This work could imply that increased PSMA, means upregulated p53 methylation, greater MDM2 expression and thus elevated cell growth. Further, DHFR has been considered as a target of second-line cancer chemotherapy, due to its role in tetrahydrofolate synthesis, which is essential for cellular synthesis of DNA, RNA, thymidylates and proteins. As mentioned, this leads DHFR to be highly sensitive to tetrahydrofolate analogs such as methotrexate (MTX) [105]. Therefore, it may be possible that MDM2 inhibition sensitises the effects of certain DHFR-targeted therapy, or promotes the function of PSMA in cancer cells through the response of DHFR (hypothesis of interplay summarized in Figure 1).

MDM2 and PSMA have been proved to promote the activity of matrix metalloproteinases (MMPs), such as MMP-2 and MMP-9, which are secreted by cancer cells and degrade the extracellular matrix, allowing cells to migrate, invade and move from the primary cancer site $[88,94,95,97,106]$. The endogenous inhibitors 
of MMP activity are the tissue inhibitors of metalloproteinases (TIMPs). Recently, it has been suggested in a number of papers that HIF-1 $\alpha$ is a regulator of TIMPs [107], specifically TIMP-1 [108], and the levels of MMP-2 and MMP-9 have been seen to correlate with higher levels of HIF-1 $\alpha$ in polytetrafluoroethylene grafts of patients [109]. Therefore, given the evidence that MDM2 activates HIF-1 $\alpha$, we hypothesize that both PSMA and MDM2 play a role in the regulation of MMPs during hypoxia. Additionally, VEGF induces

\section{Executive summary}

\section{Tumorigenesis \& clinical relevance of MDM2}

- Involved in both p53-dependent and -independent roles in the cell.

- Important in transformation of cells and its overexpression frequently observed in many human cancers, meaning it is a good therapeutic target.

MDM2 as a therapeutic target

- Therapeutics aim to decrease protein levels, thus reactivating p53. Undertaken through: reducing protein levels in cancer cells, inhibiting E3 ubiquitin ligase activity or disruption of interaction with p53.

- No ideal therapy involving MDM2 has been identified, but studies are ongoing and still viewed as a promising target.

Clinical relevance of prostate-specific membrane antigen (PSMA)

- Known to play a role in folate metabolism and hydrolyse neurotransmitter $\mathrm{N}$-acetylaspartylglutamic acid.

- Expression increases in metastasised and later stage/grade cancers.

- Excellent target for therapy: specific expression (prostate, kidneys, nervous system and small intestine), large extracellular region, transmembrane protein, internalization sequence and peptidase activity (activation of prodrug).

\section{PSMA as a biomarker}

- Since there is a positive correlation between PSMA and adverse clinical outcome, it has been suggested and studied as a biomarker for prostate cancer progression.

- More sensitive and specific than PSA detection.

- Currently, second-generation antibodies which bind extracellular epitopes are under trial. One of these, J591 has shown potential in imaging of prostate cancer.

PSMA as a therapeutic target

- PSMA has been targeted using many different strategies: antibody-based radiotherapy, antibody-drug conjugates, prodrug therapy and immunotherapy.

- There is yet to be a clinically important effect on survival in patients due to PSMA-based therapeutics.

Tumor-associated angiogenesis mediated by MDM2 and PSMA

- MDM2 and VEGF levels are coordinated in cancer.

- HIF1 $\alpha$ is regulated by MDM2 and through this can upregulate VEGF expression during hypoxia. It is not known if $\mathrm{p} 53$ is involved in this interaction.

- There may be different points of regulation of VEGF by MDM2 - at gene and protein level - some may involve p53, some may not.

- PSMA also linked to VEGF in some reports but its involvement in angiogenesis has been said to be VEGFindependent in others.

- PSMA involved in autoregulatory feedback loop in endothelial cells where it increases integrin signal transduction, PAK activation, followed by endothelial cell adhesion and invasion.

Participation of MDM2 and PSMA in tumor invasion \& metastasis

- Both proteins have been linked to MMPs: MMP-2 and MMP-9.

- Overexpression of MDM2 has been linked to increased migration and invasion in breast cancer cell lines.

- Overexpression of PSMA has been linked to decreased migration and invasion in prostate cancer cell lines.

- PSMA and MDM2 expression is linked in prostate cancer cells (published data) and breast cancer cells (our own unpublished data), with decreased PSMA protein expression leading to a significant decrease in MDM2 gene expression.

The signaling pathways of MDM2 and PSMA are intertwined by DHFR and HIF1

- MDM2 linked to DHFR, a key enzyme in folate metabolism.

- PSMA could be involved in the expression/activity of MDM2 through aberrant regulation of p53.

- MDM2 inhibition may sensitise the effects of certain DHFR-targeted therapy or promote function of PSMA in cancer cells through response of DHFR.

- PSMA and MDM2 may coordinate to regulate MMPs during hypoxia.

- Both MDM2 and PSMA could mediate angiogenesis through PI3K pathways and this could permit exertion of a synergetic pro-angiogenic effect between the proteins. 
angiogenesis partly through activation of the P13K signaling pathway in endothelial cells [110] and integrin, which is known to be regulated by PSMA in endothelial cells, can also activate P13 through p21-activated kinase (PAK) [89]; as well as MDM2 being shown to regulate HIF-1 $\alpha$ in a PTEN/PI3K-dependent manner [69]. Thus, both MDM2 and PSMA could mediate angiogenesis or, in particular, hypoxia-mediated angiogenesis, through PI3K pathways and this could permit the exertion of a synergetic pro-angiogenic effect between the proteins [40].

\section{Future perspective}

Although, to date, no ideal therapeutics targeted to MDM2 or PSMA have been identified, an understanding of their interaction could make the future for these fields bright. First, since none of the routes of MDM2targeting have shown satisfactory results in clinical trials, the observation that PSMA siRNA can decrease MDM2 transcript levels [98] could provide another way of lessening MDM2 protein levels in tumor cells. This is an even more enticing idea when the expression of PSMA solely on tumor cells in most areas of the body

\section{References}

Papers of special note have been highlighted as: • of interest; • of considerable interest.

1 Mendrysa SM, McElwee MK, Michalowski J, O’Leary KA, Young KM, Perry ME. mdm2 Is critical for inhibition of $\mathrm{p} 53$ during lymphopoiesis and the response to ionizing irradiation. Mol. Cell. Biol. 23(2), 462-472 (2003).

2 Lahav G. Oscillation by the p53-Mdm 2 feedback loop. $A d v$. Exp. Medicial Biol. 641, 28-38 (2008).

3 Moll UM, Petrenko O. The MDM2-p53 Interaction. Mol. Cancer Res. 1(14), 1001-1008 (2003).

4 Lubet R, Wang Y, Zhang Z, You M. Mouse models incorporating alterations in the major tumor suppressor genes P53 and P16: their use in screening for potential carcinogens, developing further relevant mouse models, and screening for potential chemopreventive and chemotherapeutic agents. Exp. Lung Res. 31(1), 117-133 (2005).

5 Bouska A, Eischen CM. MDM2 affects genome stability independent of p53. Cancer Res. 69(5), 1697-1701 (2009).

6 Rayburn E, Zhang R, He J, Wang H. MDM2 and human malignancies: expression, clinical pathology, prognostic markers, and implications for chemotherapy. Curr. Cancer Drug Targets 5, 27-41 (2005).

7 Wade M, Li Y-C, Wahl GM. MDM2, MDMX and p53 in oncogenesis and cancer therapy. Nat. Rev. Cancer 13(2), 83-96 (2013).

8 Kole R, Krainer AR, Altman S. RNA therapeutics: beyond RNA interference and antisense oligonucleotides. Nat. Rev. Drug Discov. 11(2), 125-140 (2012).

9 Zhang Z, Wang H, Li M, Agrawal S, Chen X, Zhang R. MDM2 is a negative regulator of $\mathrm{p} 21 \mathrm{WAF} 1 / \mathrm{CIP} 1$, is considered. Another therapeutic potential of this interaction could be the dual targeting of the proteins, to further lower MDM2 and PSMA levels in cells. Thus, further investigation of the interaction of these proteins is likely key to the improvement of MDM2and PSMA-targeted therapeutics.

\section{Financial \& competing interests disclosure}

The authors have no relevant affiliations or financial involvement with any organization or entity with a financial interest in or financial conflict with the subject matter or materials discussed in the manuscript. This includes employment, consultancies, honoraria, stock ownership or options, expert testimony, grants or patents received or pending, or royalties.

No writing assistance was utilized in the production of this manuscript.

\section{Open access}

This work is licensed under the Creative Commons Attribution-NonCommercial 4.0 Unported License. To view a copy of this license, visit http://creativecommons.org/licenses/bync-nd/4.0/

independent of p53. J. Biol. Chem. 279(16), 16000-16006 (2004).

10 Brooks CL, Gu W. Ubiquitination, phosphorylation and acetylation: the molecular basis for $\mathrm{p} 53$ regulation. Curr. Opin. Cell Biol. 15, 164-171 (2003).

11 Yang Y, Ludwig RL, Jensen JP et al. Small molecule inhibitors of HDM2 ubiquitin ligase activity stabilize and activate p53 in cells. Cancer Cell 7(6), 547-559 (2005).

12 Vassilev LT. MDM2 inhibitors for cancer therapy. Trends Mol. Med. 13(1), 23-31 (2007).

13 Vassilev LT, Vu BT, Graves B et al. In vivo activation of the p53 pathway by small-molecule antagonists of MDM2. Science 303(5659), 844-848 (2004).

14 Shen H, Maki CG. Pharmacologic activation of $\mathrm{p} 53$ by small-molecule MDM2 antagonists. Curr. Pharm. Des. 17(6), 560-568 (2011).

15 Tovar C, Rosinski J, Filipovic Z et al. Small-molecule MDM2 antagonists reveal aberrant $\mathrm{p} 53$ signaling in cancer: implications for therapy. Proc. Natl Acad. Sci. USA 103, 1888-1893 (2006).

16 Zhao Y, Aguilar A, Bernard D, Wang S. Small-molecule inhibitors of the MDM2 - p53 protein - protein interaction (MDM2 inhibitors) in clinical trials for cancer treatment. J. Med. Chem. 58, 1038-1052 (2015).

17 Bernard D, Zhao Y, Wang S. AM-8553: a novel MDM2 inhibitor with a promising outlook for potential clinical development. J. Med. Chem. 55, 4934-4935 (2012).

18 Sun D, Li Z, Rew Y et al. Discovery of AMG 232, a potent, selective, and orally bioavailable MDM2 - p53 inhibitor in clinical development. J. Med. Chem. 57(4), 1454-1472 (2014). 
19 Vu B, Wovkulich P, Pizzolato G et al. Discovery of RG7112: a small-molecule MDM2 inhibitor in clinical development. ACS Med. Chem. Lett. 4, 466-469 (2013).

20 Ding Q, Zhang Z, Liu J et al. Discovery of RG7388, a potent and selective p53 - MDM2 inhibitor in clinical development. J. Med. Chem. 56(14), 5979-5983 (2013).

21 Parks DJ, LaFrance LV, Calvo RR et al. 1,4-Benzodiazepine2,5-diones as small molecule antagonists of the HDM2-p53 interaction: discovery and SAR. Bioorganic Med. Chem. Lett. 15, 765-770 (2005).

22 Grasberger BL, Lu T, Schubert C et al. Discovery and cocrystal structure of benzodiazepinedione HDM2 antagonists that activate $\mathrm{p} 53$ in cells. J. Med. Chem. 48, 909-912 (2005).

Wang S, Sun W, Zhao Y et al. SAR405838: An optimized inhibitor of MDM2-p53 interaction that induces complete and durable tumor regression. Cancer Res. 74(20), 5855-5866 (2014).

24 Gudkov AV, Komarova EA. The role of $\mathrm{p} 53$ in determining sensitivity to radiotherapy. Nat. Rev. Cancer 3, 117-129 (2003).

25 Mendrysa SM, O'Leary KA, McElwee MK et al. Tumor suppression and normal aging in mice with constitutively high p53 activity. Genes Dev. 20, 16-21 (2006).

26 ClinicalTrials.gov. Search results for $\mathrm{mdm} 2$. https://clinicaltrials.gov

27 Mhawech-Fauceglia P, Zhang S, Terracciano L et al. Prostate-specific membrane antigen (PSMA) protein expression in normal and neoplastic tissues and its sensitivity and specificity in prostate adenocarcinoma: An immunohistochemical study using mutiple tumour tissue microarray technique. Histopathology 50, 472-483 (2007).

Šácha P, Záme ník J, Ba inka C et al. Expression of glutamate carboxypeptidase II in human brain. Neuroscience 144, 1361-1372 (2007).

29 Halsted CH, Ling E, Luthi-carter R, Villanueva JA, Gardner JM, Coyle JT. Folylpoly- $\gamma$-glutamate carboxypeptidase from Pig Jejunum. J. Biol. Chem. 273(32), 20417-20424 (1998).

30 Ristau BT, O'Keefe DS, Bacich DJ. The prostate-specific membrane antigen: lessons and current clinical implications from 20 years of research. Urol. Oncol. 32(3), 272-279 (2014).

31 Neale JH, Bzdega T, Wroblewska B. $\mathrm{N}$-acetylaspartylglutamate: The most abundant peptide neurotransmitter in the mammalian central nervous system. J. Neurochem. 75, 443-452 (2000).

32 Ross JS, Sheehan CE, Fisher HA et al. Correlation of primary tumor prostate-specific membrane antigen expression with disease recurrence in prostate cancer. Clin. Cancer Res. 9(19), 6357-6362 (2003).

33 Perner S, Hofer MD, Kim R et al. Prostate-specific membrane antigen expression as a predictor of prostate cancer progression. Hum. Pathol. 38, 696-701 (2007).

34 Liu T, Nedrow-Byers JR, Hopkins MR et al. Targeting prostate cancer cells with a multivalent PSMA inhibitorguided streptavidin conjugate. Bioorganic Med. Chem. Lett. 22(12), 3931-3934 (2012).
35 Wolf P. Prostate Specific Membrane Antigen as Biomarker and Therapeutic Target for Prostate Cancer. Prostate Cancer - Diagnostic and Therapeutic. Advances. (2011). http://cdn.intechopen.com/pdfs-wm/24242.pdf

36 Chang SS, Heston WDW. The clinical role of prostatespecific membrane antigen (PSMA). Urol. Oncol. 7, 7-12 (2002).

37 Rajasekaran A, Anilkumar G, Christiansen JJ. Is prostatespecific membrane antigen a multifunctional protein? Am. J. Physiol. Cell Physiol. (67), 975-981 (2005).

38 Akhtar NH, Pail O, Saran A, Tyrell L, Tagawa ST. Prostatespecific membrane antigen-based therapeutics. Adv. Urol. 2012, 973820 (2012).

39 Lapidus RG, Tiffany CW, Isaacs JT, Slusher BS. Prostatespecific membrane antigen (PSMa) enzyme activity is elevated in prostate cancer cells. Prostate 45 (4), 350-354 (2000).

40 Burger MJ, Tebay MA, Keith PA et al. Expression analysis of delta-catenin and prostate-specific membrane antigen: their potential as diagnostic markers for prostate cancer. Int. J. Cancer 100(2), 228-237 (2002).

41 Bernacki KD, Fields KL, Roth MH. The utility of PSMA and PSA immunohistochemistry in the cytologic diagnosis of metastatic prostate carcinoma. Diagn. Cytopathol. 42(7), 1-5 (2013).

42 Zhang L, Wang C-Y, Yang R et al. Real-time quantitative RT-PCR assay of prostate-specific antigen and prostatespecific membrane antigen in peripheral blood for detection of prostate cancer micrometastasis. Urol. Oncol. 26(6), 634-640 (2008).

43 Wynant GE, Murphy GP, Horoszewicz JS et al. Immunoscintigraphy of prostatic cancer: preliminary results with 111In-labeled monoclonal antibody 7E11-C5-3 (CYT356). Prostate 18(3), 229-241 (1991).

44 Elsässer-Beile U, Reischl G, Wiehr S et al. PET imaging of prostate cancer xenografts with a highly specific antibody against the prostate-specific membrane antigen. J. Nucl. Med. 50(4), 606-611 (2009).

45 Apolo AB, Pandit-Taskar N, Morris MJ. Novel tracers and their development for the imaging of metastatic prostate cancer. J. Nucl. Med. 49, 2031-2041 (2008).

Rosenthal SA, Haseman MK, Polascik TJ. Utility of capromab pendetide (ProstaScint) imaging in the management of prostate cancer. Tech. Urol. 7(1), 27-37 (2001).

47 Nargund V, Al Hashmi D, Kumar P et al. Imaging with radiolabelled monoclonal antibody (MUJ591) to prostate-specific membrane antigen in staging of clinically localized prostatic carcinoma: Comparison with clinical, surgical and histological staging. BJU Int. 95, 1232-1236 (2005).

48 Regino C, Wong K, Milenic D et al. Preclinical evaluation of a monoclonal antibody (3C6) Specific for prostatespecific membrane antigen. Curr. Radiopharm. 2(1), 9-17 (2009).

49 Foss CA, Mease RC, Fan H et al. Radiolabeled smallmolecule ligands for prostate-specific membrane antigen: 
in vivo imaging in experimental models of prostate cancer. Clin. Cancer Res. 11(11), 4022-4028 (2005).

50 Mease RC, Dusich CL, Foss CA et al. $\left[{ }^{18} \mathrm{~F}\right]$ fluorobenzyl-L-cysteine, $\left[{ }^{18} \mathrm{~F}\right] \mathrm{DCFBC}$ : a new imaging probe for prostate cancer cysteine, $\left[{ }^{18} \mathrm{~F}\right]$ DCFBC: a new imaging probe for prostate cancer. 14(10), 3036-3043 (2008).

51 Chen Y, Dhara S, Banerjee S. A low molecular weight PSMA-based fluorescent imaging agent for cancer. Biochem. Biophys. Res. Commun. 90(3), 624-629 (2009).

52 Hiller SM, Maresca KP, Femia FJ et al. Preclinical evaluation of novel glutamate-urea-lysine analogs that target prostate specific membrane antigen as molecular imaging pharmaceuticals for prostate cancer. Cancer Res. 69(17), 6932-6940 (2009).

53 Osborne JR, Akhtar NH, Vallabhajosula S, Anand A, Deh $\mathrm{K}$, Tagawa ST. Prostate-specific membrane antigen-based imaging. Urol. Oncol. Semin. Orig. Invest. 31(2), 144-154 (2013).

54 Sokoloff R, Norton KC, Gasior CL, Marker KM, Grauer LS. A dual-monoclonal sandwich assay for prostate-specific membrane antigen: levels in tissues, seminal fluid and urine. Prostate 43(2), 150-157 (2000).

55 Bander NH, Milowsky MI, Nanus DM, Kostakoglu L, Vallabhajosula S, Goldsmith SJ. Phase I trial of 177lutetium-labeled J591, a monoclonal antibody to prostate-specific membrane antigen, in patients with androgen-independent prostate cancer. J. Clin. Oncol. 23(21), 4591-4601 (2005).

56 Tagawa ST, Akhtar NH, Pail O, Saran A, Tyrell L. Prostatespecific membrane antigen-based therapeutics. Adv. Urol. 2012, 973820 (2012).

57 Galsky MD, Eisenberger M, Moore-Cooper S et al. Phase I trial of the prostate-specific membrane antigen-directed immunoconjugate MLN2704 in patients with progressive metastatic castration-resistant prostate cancer. J. Clin. Oncol. 26(13), 2147-2154 (2008).

58 Huang X, Bennett M, Thorpe PE. Anti-tumor effects and lack of side effects in mice of an immunotoxin directed against human and mouse prostate-specific membrane antigen. Prostate 61(1), 1-11 (2004).

59 Russell PJ, Hewish D, Carter T et al. Cytotoxic properties of immunoconjugates containing melittin-like peptide 101 against prostate cancer: in vitro and in vivo studies. Cancer Immunol. Immunother. 53, 411-421 (2004).

60 Ma D, Hopf CE, Malewicz AD et al. Potent antitumor activity of an auristatin-conjugated, fully human monoclonal antibody to prostate-specific membrane antigen. Clin. Cancer Res. 12(8), 2591-2596 (2006).

61 Denmeade SR, Mhaka AM, Rosen M et al. Engineering a Prostate-Specific Membrane Antigen-Activated Tumor Endothelial Cell Prodrug for Cancer Therapy. Sci. Transl. Med. 4(140), 2-22 (2012).

62 Jeske SJ, Milowsky MI, Smith CA, Smith KA, Bander NH, Nanus DM et al. Phase II trial of the anti-prostate specific membrane antigen (PSMA) monoclonal antibody (mAb) J591 plus low-dose interleukin-2 (IL-2) in patients (pts) with recurrent prostate. ASCO Annual Meeting Proceedings. 25(Suppl. 18), 15558 (2007).
63 ClinicalTrials.gov. Search results for PSMA. https://clinicaltrials.gov

64 Narasimhan M, Rose R, Karthikeyan M, Rathinavelu A. Detection of HDM2 and VEGF co-expression in cancer cell lines: novel effect of HDM2 antisense treatment on VEGF expression. Life Sci. 81, 1362-1372 (2007).

65 Narasimhan M, Rose R, Ramakrishnan R, Zell JA, Rathinavelu A. Identification of HDM2 as a regulator of VEGF expression in cancer cells. Life Sci. 82, 1231-1241 (2008).

- Highlights a link between MDM2 and VEGF, which had been done before, but studied their interaction in detail. They found that overexpression and inhibition of MDM2 in prostate cancer caused the same state of VEGF protein. The group also investigated the result of tumor-conditioned media on HUVECs and found that decreased MDM2 in cancer cells led to decreased VEGF secretion and angiogenesis.

66 Ivan M, Kondo K, Yang $\mathrm{H}$ et al. HIFalpha targeted for VHLmediated destruction by proline hydroxylation: implications for $\mathrm{O}_{2}$ sensing. Science 292(5516), 464-468 (2001).

67 Jaakkola P, Mole DR, Tian YM et al. Targeting of HIF-alpha to the von Hippel-Lindau ubiquitylation complex by $\mathrm{O}_{2}$ regulated prolyl hydroxylation. Science 292(5516), 468-472 (2001).

68 Mahon PC, Hirota K, Semenza GL. FIH-1: a novel protein that interacts with HIF-1 $\alpha$ and VHL to mediate repression of HIF-1 transcriptional activity. Genes Dev. 15, 2675-2686 (2001).

69 Joshi S, Singh Alok R, Durden DL. MDM2 regulates hypoxic hypoxia-inducible factor la stability in an E3 ligase, proteasome, and PTEN-phosphatidylinositol 3-kinase-AKT-dependent manner. J. Biol. Chem. 289(33), 22785-22797 (2014).

70 Bos R, Van Diest PJ, De Jong JS, Van Der Groep P, Van Der Valk P, Van Der Wall E. Hypoxia-inducible factor$1 \alpha$ is associated with angiogenesis, and expression of bFGF, PDGF-BB, and EGFR in invasive breast cancer. Histopathology 46, 31-36 (2005).

71 Nakanishi K, Hiroi S, Tominaga S et al. Expression of hypoxia-inducible factor-1alpha protein predicts survival in patients with transitional cell carcinoma of the upper urinary tract. Clin. Cancer Res. 11(7), 2583-2590 (2005).

72 Theodoropoulos VE, Lazaris AC, Sofras F et al. Hypoxiainducible factor 1 alpha expression correlates with angiogenesis and unfavorable prognosis in bladder cancer. Eur. Urol. 46, 200-208 (2004).

73 Zagzag D, Zhong H, Scalzitti JM, Laughner E, Simons JW, Semenza GL. Expression of hypoxia-inducible factor 1alpha in brain tumors: association with angiogenesis, invasion and progression. Cancer. 88(11), 2606-2618 (2000).

74 Graeber TG, Osmanian C, Jacks T et al. Hypoxia-mediated selection of cells with diminished apoptotic potential in solid tumours. Nature 379(6560), 88-91 (1996).

75 Nieminen A-L, Qanungo S, Schneider EA, Jiang B-H, Agani FH. Mdm2 and HIF-1alpha interaction in tumor cells during hypoxia. J. Cell. Physiol. 204, 364-369 (2005).

76 Lau CK, Yang ZF, Lam CT, Tam KH, Poon RTP, Fan ST Suppression of hypoxia inducible factor- $1 \alpha$ (HIF-1 $\alpha$ ) by 
YC-1 is dependent on murine double minute 2 (Mdm2). Biochem. Biophys. Res. Commun. 348, 1443-1448 (2006).

77 Secchiero P, Corallini F, Gonelli A et al. Antiangiogenic activity of the MDM2 antagonist nutlin-3. Circ. Res. 100, 61-69 (2007).

78 LaRusch GA, Jackson MW, Dunbar JD, Warren RS, Donner DB, Mayo LD. Nutlin3 blocks vascular endothelial growth factor induction by preventing the interaction between hypoxia inducible factor $1 \alpha$ and $\mathrm{Hdm} 2$. Cancer Res. 67, 450-454 (2007).

79 Binder BR. A novel application for murine double minute 2 antagonists: the p 53 tumor suppressor network also controls angiogenesis. Circ. Res. 100, 13-14 (2007).

80 Lee YM, Lim JH, Chun YS et al. Nutlin-3, an Hdm2 antagonist, inhibits tumor adaptation to hypoxia by stimulating the FIH-mediated inactivation of HIF-1 $\alpha$. Carcinogenesis 30 (10), 1768-1775 (2009).

81 Lando D, Peet DJ, Gorman JJ, Whelan DA, Whitelaw ML, Bruick RK. FIH-1 is an asparaginyl hydroxylase enzyme that regulates the transcriptional activity of hypoxia-inducible factor. Genes Dev. 16(214), 1466-1471 (2002).

82 Zhou S, Gu L, He J, Zhang H, Zhou M. MDM2 regulates vascular endothelial growth factor mRNA stabilization in hypoxia. Mol. Cell. Biol. 31(24), 4928-4937 (2011).

- States that MDM2 regulates VEGF at mRNA level, which is another level of regulation than that which had previously been studied. Therefore, this could be important in the understanding of MDM2 and VEGF interaction.

83 Xiong J, Yang Q, Li J, Zhou S. Effects of MDM2 inhibitors on vascular endothelial growth factor-mediated tumor angiogenesis in human breast cancer. Angiogenesis 17(1), 37-50 (2013).

84 Muthumani P, Alagarsamy K, Dhandayuthapani S, Venkatesan T, Rathinavelu A. Pro-angiogenic effects of MDM2 through HIF- $1 \alpha$ and NF- $\kappa B$ mediated mechanisms in LNCaP prostate cancer cells. Mol. Biol. Rep. 41, 5533-5541 (2014).

85 Levy AP, Levy NS, Goldberg MA. Hypoxia-inducible protein binding to vascular endothelial growth factor mRNA and its modulation by the von Hippel-Lindau protein. J. Biol. Chem. 271(41), 25492-25497 (1996).

86 Ravi R, Mookerjee B, Bhujwalla ZM et al. Regulation of tumor angiogenesis by $\mathrm{p} 53$-induced degradation of hypoxia-inducible factor 1alpha. Genes Dev. 14, 34-44 (2000).

87 Tsui P, Rubenstein M, Guinan P. Correlation between PSMA and VEGF expression as markers for LNCaP tumor angiogenesis. J. Biomed. Biotechnol. 2005, 287-290 (2005).

88 Zhao LY, Mao XP, Chao KY, Guo SJ, Qiu SP. Prostatespecific membrane antigen can promote in vivo osseous metastasis of prostate cancer cells in mice. Brazilian J. Med. Biol. Res. 45(8), 737-745 (2012).

89 Conway RE, Petrovic N, Li Z, Heston W, Wu D, Shapiro LH. Prostate-specific membrane antigen regulates angiogenesis by modulating integrin signal transduction. Mol. Cell. Biol. 26, 5310-5324 (2006).
90 Grant CL, Caromile LA, Durrani K et al. Prostate specific membrane antigen (PSMA) regulates angiogenesis independently of VEGF during ocular neovascularization. PLoS ONE 7(7) (2012).

91 Gialeli C, Theocharis AD, Karamanos NK. Roles of matrix metalloproteinases in cancer progression and their pharmacological targeting. FEBS J. 278, 16-27 (2011).

92 Yang LMC, Tam PY, Murray BJ et al. Virus electrodes for universal biodetection. Anal. Chem. 78(10), 3265-3270 (2006).

93 Rajabi P, Karimian P, Heidarpour M. The relationship between MDM2 expression and tumor thickness and invasion in primary cutaneous malignant melanoma. J. Res. Med. Sci. 17(5), 452-455 (2012).

94 Chen X, Qiu J, Yang D et al. MDM2 promotes invasion and metastasis in invasive ductal breast carcinoma by inducing matrix metalloproteinase-9. PLoS ONE 8(11), e78794 (2013).

95 Zhang DH, Zhang LY, Liu DJ, Yang F, Zhao JZ. Expression and significance of MMP-9 and MDM2 in the oncogenesis of lung cancer in rats. Asian Pac. J. Trop. Med. 7(7), 585-588 (2014).

96 Ghosh A, Wang X, Klein E, Heston WDW. Novel role of prostate-specific membrane antigen in suppressing prostate cancer invasiveness. Cancer Res. 65(8), 727-731 (2005).

- Presents interesting results which were the opposite of what would be expected of PSMA. The group claimed to see that decreased PSMA levels in prostate cancer cells led to an increased invasion. This could provide an insight into the mechanisms of action of PSMA.

97 Conway RE, Joiner K, Patterson A et al. Prostate specific membrane antigen produces pro-angiogenic laminin peptides downstream of matrix metalloprotease-2. Angiogenesis 16, 847-860 (2013).

- This study was the first to provide a mechanism proposla for the interaction of PSMA with the matrix metalloproteinases. It is suggested that PSMA works downstream of MMP-2 to produce small peptides to enchance the invasion and adhesion of HUVECs in vitro.

98 Xu L, Wang Z, Li X-F et al. Screening and identification of significant genes related to tumor metastasis and PSMA in prostate cancer using microarray analysis. Oncol. Rep. 30(4), 1920-1928 (2013).

-• This study was the first to link the expression of PSMA to MDM2. The group treated prostate cancer cells with PSMA-targeted siRNA and found that this caused a highly significant decrease in MDM2 gene expression levels.

99 Yao V, Bacich DJ. Prostate specific membrane antigen (PSMA) expression gives prostate cancer cells a growth advantage in physiologically relevant folate environment in vitro. Prostate 66, 867-875 (2006).

100 Maguire M, Nield PC, Devling T et al. MDM2 regulates dihydrofolate reductase activity through monoubiquitination. Cancer Res. 68(9), 3232-3242 (2008).

- Proposes a regulation of DHFR, a key enzyme in folate metabolism, by MDM2 ubiquitin ligase activity. If this 
is the case, MDM2 and PSMA play close roles in folate metabolism and this could be a clue to their interaction.

101 Schnell JR, Dyson HJ, Wright PE. Effect of cofactor binding and loop conformation on side chain methyl dynamics in dihydrofolate reductase. Biochemistry 43, 374-383 (2004).

102 Askari BS, Krajinovic M. Dihydrofolate reductase gene variations in susceptibility to disease and treatment outcomes. Curr. Genomics 11, 578-583 (2010).

103 Bird AP. The relationship of DNA methylation to cancer. J. Cancer Surviv. 26, 87-101 (1996).

104 Pogribny IP, Miller BJ, James SJ. Alterations in hepatic p53 gene methylation patterns during tumor progression with folate/methyl deficiency in the rat. Cancer Lett. 115, 31-38 (1997).

105 Rajagopalan PTR, Zhang Z, McCourt L, Dwyer M, Benkovic SJ, Hammes GG. Interaction of dihydrofolate reductase with methotrexate: ensemble and single-molecule kinetics. Proc. Natl Acad. Sci. USA 99(21), 13481-13486 (2002).

106 Syed I, Rathod J, Parmar M, Corcoran GB, Ray SD. Matrix metalloproteinase- $9,-10$, and -12, MDM2 and p 53 expression in mouse liver during dimethylnitrosamineinduced oxidative stress and genomic injury. Mol. Cell. Biochem. 365, 351-361 (2012).

107 Fujiwara S, Nakagawa K, Harada $\mathrm{H}$ et al. Silencing hypoxiainducible factor-1alpha inhibits cell migration and invasion under hypoxic environment in malignant gliomas. Int. J. Oncol. 30, 793-802 (2007).

108 Cui H, Seubert B, Stahl E et al. Tissue inhibitor of metalloproteinases-1 induces a pro-tumourigenic increase of miR-210 in lung adenocarcinoma cells and their exosomes. Oncogene 34(28), 1-11 (2014).

109 Misra S, Fu AA, Rajan DK et al. Expression of hypoxia inducible factor- $1 \alpha$, macrophage migration inhibition factor, matrix metalloproteinase- 2 and -9 , and their inhibitors in hemodialysis grafts and arteriovenous fistulas. J. Vasc. Interv. Radiol. 19(2), 252-259 (2008).

110 Abid MR, Guo S, Minami T et al. Vascular endothelial growth factor activates PI3K/Akt/Forkhead signaling in endothelial cells. Arterioscler. Thromb. Vasc. Biol. 24, 294-300 (2004). 